\title{
Lojalność konsumentów wobec wybranych marek smartfonów
}

\author{
Marcin Krzaczek* \\ Marek Reysowski**
}

\section{Lojalność w ujęciu behawioralnym}

Lojalność jest źródłem trwałej przewagi konkurencyjnej (Dick, Basu 1994), dlatego też budowanie lojalności nabywcy jest jednym z głównych celów firm działających na rynku B2C. Należałoby wyjść z założenia, że podstawą budowania lojalności powinna być silna marka, jednak nabywcy na jednym rynku mogą okazać się bardzo lojalni wobec wybranej marki, a na innym rynku - całkowicie nielojalni wobec tej samej marki. Może się to wiązać oczywiście z różnym poziomem konkurencji na tych rynkach, ale trzeba w tym wypadku pamiętać o zmiennym zachowaniu nabywcy w zależności od analizowanej grupy produktowej (Kahn, Kalwani 1986).

Początkowo lojalność łączono z samym procesem kupowania (purchasing behaviour), ale nawet w tym przypadku trudno było znaleźć jednolitą interpretację tego pojęcia. Część autorów za najważniejsze uważała kupowanie najczęściej jednej wybranej marki w dłuższym okresie (percent of purchase definition) (Cunningham 1956), a dla innych najważniejsza była sekwencja następujących po sobie zakupów tej samej marki (McConnell 1968; Tucker 1964). Spory pojawiły się w przypadku określenia minimalnej liczby tych zakupów - możemy mieć do czynienia z sytuacją, w której spełniony zostanie kluczowy warunek, ale trudno będzie uznać zachowanie nabywcy za lojalne. Zgodnie z definicją lojalności, jeśli chodzi o wybór pomiędzy dwiema markami, A i B, za lojalnego nabywcę marki A uznać należy tego, w przypadku którego liczba zakupionych produktów

* Marcin Krzaczek - doktor nauk ekonomicznych, Uniwersytet Gdański, Wydział Ekonomiczny, Katedra Biznesu Międzynarodowego, Zakład Strategii Marketingowych, marcin.krzaczek@ug.edu.pl ** Marek Reysowski - doktor nauk ekonomicznych, Uniwersytet Gdański, Wydział Ekonomiczny, Katedra Biznesu Międzynarodowego, Zakład Strategii Marketingowych, marek.reysowski@, ug.edu.pl 
marki A stanowi ponad 50\% liczby wszystkich zakupionych produktów w określonym przedziale czasowym (Brown 1952). Problem pojawia się wtedy, kiedy pomimo mniejszego udziału w całym badanym okresie zakupy marki B dominują w końcowej fazie. Sprawa komplikuje się jeszcze bardziej, gdy wybieramy pomiędzy trzema markami, ponieważ udział zakupów konkretnej marki przekraczający jedną trzecią zgodnie $\mathrm{z}$ definicją pozwala określić nabywcę jako lojalnego (Cunningham 1956). Pojawiają się także opinie, że ciężko uznać nabywcę za lojalnego wobec marki, jeżeli w tym samym czasie w równym stopniu kupuje on produkty konkurencyjnej marki (Givon 1984). Zgodnie z jeszcze bardziej radykalnym podejściem, nawet jeżeli prawdopodobieństwo wyboru konkretnej marki jest największe, ale z powodu wielości alternatyw w liczbach bezwzględnych nie jest wysokie, takiego zachowania nie można utożsamiać z lojalnością. Ten sposób należałoby wręcz uznać za poszukiwanie różnorodności (Kahn, Kalwani 1986). Czynniki zewnętrzne mogą być przyczyną zmiany marki, ale te w większym stopniu wpływają na osłabienie stosunku do produktu (relative attitude), gdy zaangażowanie nabywcy w proces zakupu jest mniejsze, podobnie jak różnice między analizowanymi produktami (Van Trijp, Hoyer, Inman 1996). Oczywiście samo postrzeganie różnic zależy bezpośrednio od rodzaju nabywanych przez klienta produktów, np. w przypadku żywności poszukiwanie alternatyw będzie bardziej intensywne (Jensen, Hansen 2006).

W sytuacji, w której konsekwentne dokonywanie zakupu (purchasing behaviour) utożsamia się z lojalnością wobec marki, kluczowe jest określenie minimalnej liczby zakupów niezbędnych do uznania zachowania za lojalne. Zgodnie z różnymi teoriami powinny to być co najmniej trzy bądź cztery następujące po sobie akty (McConnell 1968; Tucker 1964). Nie ulega wątpliwości, że pojedynczy zakup produktu nie może być uznany za lojalność wobec marki - lojalność wymaga dłuższego procesu, co dla niektórych autorów oznacza, że konieczny jest co najmniej dwukrotny zakup wybranej marki (Jacoby i Kyner 1973). W wybranych branżach większa liczba zakupów może wpłynąć na zmniejszenie poziomu lojalności (Lotko 2018).

Głównym problemem sfery pojęciowej związanym z lojalnością był problem definicji lojalności, które miały przeważnie operacyjny charakter, opisywały model zachowania nabywcy wobec marki lub grupy marek sprowadzający się najczęściej do opisywania zachowania nabywcy w przeszłości i nieuwzględniania zachowania nabywcy w przyszłości. Wynikało to poniekąd z ograniczeń badawczych, ponieważ początkowo do opisu zachowań nabywcy i jego lojalności wobec marki wykorzystywano dane pochodzące z paneli gospodarstw domowych (Jacoby, Kyner 1973; Kahn, Kalwani 1986). Problem polega na tym, że prognozy, których podstawą jest zachowanie nabywcy w przeszłości, mają istotne ograniczenia (Ewing 2000). Już na tym etapie wyraźnie widać, że sam komponent behawioralny nie jest wystarczający, aby odpowiednio zdefiniować lojalność wobec 
marki, uznano zatem, że lojalność tworzą elementy zarówno behawioralne, jak i emocjonalne (attitudinal). Sam fakt dokonania zakupu nie wyjaśnia powodów tego zakupu. Definicje lojalności behawioralnej nie pomogły firmom budować czy ewentualnie modyfikować lojalności nabywcy (Jacoby, Kyner 1973; Dick, Basu 1994). Nabywanie produktu, nawet częste, niepoparte odpowiednią wewnętrzną potrzebą nabywcy nazywano nawet fałszywą lojalnością. Konieczne stało się zatem stworzenie koncepcyjnej definicji lojalności i modeli opisujących to zjawisko (Day 1969).

\section{Definicja lojalności z uwzględnieniem elementu emocjonalnego}

Definicja jest oparta na sześciu koniecznych do spełnienia warunkach. Zgodnie z nią lojalność jest (1) nieprzypadkowym (2) zachowaniem nabywcy (tzn. zakupem), (3) mającym miejsce w dłuższym czasie, (4) przy udziale grupy decyzyjnej, (5) z możliwością wyboru między markami i (6) następstwem procesu podejmowania decyzji (Jacoby, Kyner 1973). Uznanie, że działania nabywcy nie mogą mieć charakteru losowego, jest konieczne - gdyby było inaczej, poszukiwanie jakichkolwiek naukowych zależności nie miałoby sensu. Mimo że pozytywny stosunek do produktu wiąże się z procesem nabycia produktu (Cossío-Silva i in. 2016), sama chęć dokonania zakupu lub zamiar nie są wystarczające. Tak zdefiniowana lojalność wymaga intencji zakupu popartej konkretnym zachowaniem (purchasing behaviour). Jednorazowy zakup także trudno uznać za spełniający warunki lojalności, należy bowiem przyjąć, że musimy mieć do czynienia przynajmniej z dwoma następującymi po sobie zakupami (Jacoby, Kyner 1973).

Potrzebę rozbudowania koncepcyjnej definicji lojalności dostrzegali także Dick i Basu. Zaproponowali oni model, w którym dwoma nieodzownymi elementami lojalności nabywcy są względny stosunek do produktu (relative attitude) oraz zaangażowanie w powtarzalne zakupy produktu (repeat patronage) (Dick, Basu 1994). Kluczowe dla wyjaśnienia zjawiska lojalności jest określenie przede wszystkim stosunku nabywcy do produktu, ale nie można zapomnieć też o samym procesie zakupu - bez niego nawet najbardziej pozytywny stosunek do produktu nie prowadziłby do lojalności. Dodatkowo duże zaangażowanie w proces zakupu samo w sobie jest źródłem budowania pozytywnego stosunku do produktu (Jensen, Hansen 2006).

Aby określić względny stosunek nabywcy do produktu, należy przeanalizować czynniki determinujące ten stosunek. Tradycyjne modele wyróżniają trzy grupy czynników wpływających na stosunek do produktu: 
1. czynniki poznawcze (cognitive), czyli te związane z poziomem informacji na temat produktu i produktów alternatywnych;

2. czynniki emocjonalne/afektywne (affective) w odniesieniu do marki;

3. czynniki konatywne (conative), czyli determinujące konkretne zachowania rynkowe, np. koszt zmiany dostawcy czy oczekiwania dotyczące rynku i produktów (Dick, Basu 1994).

Trudno przyjąć określoną hierarchię tych grup w budowaniu lojalności. Może się okazać, że w przypadku wybranych produktów dopiero równoczesna wysoka ocena czynników z różnych grup gwarantuje powodzenie (Iglesias, Singh, Batista-Foguet 2011; Şahin, Zehir, Kitapçi 2011). W innych koncepcjach zamiast wspomnianych czynników wyróżnia się grupę mierników lojalności (Sulikowski 2015), a powtarzalność zakupów jest jednym z nich (Punniyamoorthy, Prasanna Mohan Raj 2007).

Na tym etapie należy pamiętać o różnorodności samych nabywców, a co za tym idzie - o wpływie konkretnych kryteriów segmentacji na lojalność nabywcy. Na przykład zupełnie inne może być znaczenie czynników poznawczych i afektywnych dla kobiet i mężczyzn (Ndubisi 2006), osób w różnym wieku (Baloglu 2002) czy zamieszkujących różne regiony (Kabiraj, Shanmugan 2011), a podobny poziom satysfakcji różnych nabywców może oznaczać inną wielkość i częstotliwość zakupów tego samego produktu (Mittal, Kamakura 2001). Grupy scharakteryzowanych czynników tworzą swego rodzaju etapy/fazy/szczeble drabiny lojalności nabywcy (Oliver 1999; Cichosz 2003), a także profile lojalnościowe klientów (Pietrzak 2004).

Na podstawie swoich prac nad lojalnością nabywcy Dick i Basu zaproponowali macierz łączącą względny stosunek do produktu, tj. lojalność emocjonalną, z powtarzalnością zakupów, czyli lojalnością behawioralną (Dick, Basu 1994). Niski poziom zaangażowania w zakup produktu czy marki wraz z obojętnym bądź negatywnym stosunkiem do tego produktu oznacza całkowity brak lojalności. Poprawa odczuć w stosunku do produktu, której towarzyszy niski poziom zakupów, może oznaczać ukrytą lojalność (latent loyalty). Powtarzalność zakupów bez emocjonalnego zaangażowania wskazuje na lojalność fałszywą/bierną (spurious loyalty), a samych nabywców tego typu można określić jako biernie lojalnych (Knox, Walker 2001). W tym wypadku możliwa jest nawet sytuacja, w której stosunek nabywcy jest negatywny, a poziom zakupów stosunkowo wysoki (Jarvis, Mayo 1986). Tylko kombinacja ciągłych zakupów i dużego zaangażowania oznacza prawdziwą lojalność (Dick, Basu 1994; Michalska-Dudek 2013).

Poziom zaangażowania nabywcy może mieć wpływ na wybór konkretnych narzędzi marketingowych mających na celu poprawę lojalności. Konieczne może się okazać stosowanie zupełnie innych instrumentów w celu uzyskania podobnego zachowania nabywcy lojalnego i biernie lojalnego (Yi, Jeon 2003). 
Tabela 1. Macierz rodzajów lojalności (względny stosunek do marki / powtarzalność zakupów)

\begin{tabular}{|l|c|c|c|}
\cline { 3 - 4 } \multicolumn{2}{c|}{} & \multicolumn{2}{c|}{ Powtarzalne zakupy } \\
\cline { 3 - 4 } \multicolumn{2}{c|}{$\begin{array}{l}\text { Względny stosunek } \\
\text { do marki/produktu }\end{array}$} & Wysoki poziom & Niski poziom \\
\cline { 2 - 4 } & Niski poziom & Bojalność & Ukryta lojalność \\
\hline
\end{tabular}

Źródło: opracowanie własne na podstawie (Dick, Basu 1994).

Mając na uwadze przytoczone rozważania teoretyczne, autorzy postanowili ocenić poziom lojalności behawioralnej i emocjonalnej polskich użytkowników smartfonów, tj. telefonów komórkowych służących do wielozadaniowego, mobilnego przetwarzania danych (Redda, Shezi 2019). Przyczyną zainteresowania się tym rynkiem był fakt, że jest to stosunkowo nowa dziedzina przemysłu technologicznego, a przy tym niezwykle popularna wśród użytkowników.

\section{Charakterystyka rynku smartfonów}

Rynek smartfonów to jedna $\mathrm{z}$ najdynamiczniej rozwijających się $\mathrm{w}$ ostatnich latach branż ogólnoświatowych - wystarczy spojrzeć na dane sprzedażowe: w 2008 r. nabywców znalazło 140 milionów smartfonów, podczas gdy 10 lat później sprzedanych zostało ponad dziesięciokrotnie więcej tego typu urządzeń, 1,5 mld sztuk, o wartości łącznej 522 mld USD, co stanowiło blisko połowę wartości sprzedaży TCG (technical consumer goods) (Number of smartphones sold to end users worldwide 2020). Nic więc dziwnego, że największe podmioty tego rynku stały się wiodącymi korporacjami technologicznymi pod względem przychodów i odwrotnie - największe korporacje technologiczne chcą mieć możliwie największy udział w rynku telefonów komórkowych. Można dostrzec ten trend na zestawieniu największych producentów smartfonów pod względem wolumenu sprzedaży w latach 2018-2019 (Tabela 2). Znaczący udział w rynku mają zarówno ogólnoświatowe znane od kilkudziesięciu lat marki technologiczne (Apple, Samsung), jak i dynamicznie rozwijające się chińskie marki telekomunikacyjne (Huawei, Xiaomi, Oppo), które jako jedyne notują systematyczne wzrosty sprzedaży na coraz bardziej konkurencyjnym i nasyconym rynku (Worldwide Smartphone Sales to End Users by Vendor in 20192020 ).

Polski rynek tego typu urządzeń rośnie w podobnym tempie do światowego - w 2012 r. smartfon posiadało 9\% Polaków powyżej 15 roku życia, podczas gdy na początku 2018 roku było to już $61 \%$. Istotne są też ogromne różnice w penetracji rynku w zależności od grup wiekowych poszczególnych użytkowników - wśród osób w wieku 15-29 lat odsetek ten wynosił 90\%, a wśród osób w wieku 60 lat i więcej - zaledwie $23 \%$. Smartfony stają się też dominującym narzędziem dostępu do internetu - pod koniec 2017 r. odpowiadały za 40\% ogółu czasu przeznaczanego na korzystanie z internetu, przy czym należy zaznaczyć, że ta kategoria 
istotnie rośnie, ponieważ w 2018 r. polscy użytkownicy deklarowali, że na aktywności w internecie niezwiązanej z pracą zawodową spędzali przeciętnie 5 godzin i 18 minut dziennie (Mikowska, Skalna, Śliwiński 2018). Nie może więc dziwić, że rynek smartfonów w Polsce stanowi coraz istotniejszą gałąź sprzedaży dla największych firm technologicznych.

Tabela 2. Światowa sprzedaż smartfonów użytkownikom końcowym w latach 2018-2019

\begin{tabular}{|l|c|c|c|c|}
\hline \multicolumn{1}{|c|}{ Producent } & $\mathbf{2 0 1 9}(\mathbf{m l n}$ sztuk) & $\mathbf{2 0 1 9}(\mathbf{\%})$ & $\mathbf{2 0 1 8}$ (mln sztuk) & $\mathbf{2 0 1 8 ( \% )}$ \\
\hline Samsung & 296 & 19,2 & 295 & 19,0 \\
\hline Huawei & 241 & 15,6 & 203 & 13,0 \\
\hline Apple & 193 & 12,6 & 209 & 13,4 \\
\hline Xiaomi & 126 & 8,2 & 122 & 7,9 \\
\hline Oppo & 119 & 7,7 & 119 & 7,6 \\
\hline Inni & 566 & 36,7 & 607 & 39,1 \\
\hline Razem & 1541 & 100,0 & 1555 & 100,0 \\
\hline
\end{tabular}

Źródło: opracowanie własne na podstawie http://www.gartner.com/en/newsroom/press-releases/2020-03-03-gartner-says-global-smartphone-sales-fell-slightly-in (data dostępu: 20.09.2020).

Wśród polskich użytkowników smartfonów dominują takie same marki, jak na ogólnoświatowym rynku, ale ich udziały w wolumenie sprzedaży rozkładają się nieco inaczej. Pod koniec II kwartału 2020 r. liderem były ex aequo Samsung i Xiaomi - po 27\%, następnie Huawei z 18\%, a daleko za nimi Apple z 9-procentowym udziałem w rynku sprzedaży smartfonów w Polsce (Xiaomi i Samsung liderami polskiego rynku smartfonów 2020).

Na potrzeby niniejszej pracy, skupiającej się na lojalności użytkowników telefonów komórkowych, autorzy zdecydowali się porównać dwie marki: Samsung oraz Huawei - wiodące i najważniejsze marki producentów telefonów komórkowych w państwach ich pochodzenia, odpowiednio w Korei Południowej i Chinach, będące zarazem największymi sprzedawcami telefonów komórkowych na świecie w ciągu dwóch ostatnich lat.

\section{Przedstawienie marek Huawei oraz Samsung}

Huawei został założony w 1987 r. w chińskim mieście Shenzen. Warto zauważyć, że całość akcji Huawei oficjalnie należy do pracowników tego przedsiębiorstwa, jednak akcje te są w posiadaniu nie pracowników jako takich, tylko zrzeszającego ich związku zawodowego, a odchodząc z pracy, nie mogą oni zachować tychże akcji, można więc stwierdzić - mając na uwadze umiejscowienie związków zawodowych w strukturze władz ChRL - że Huawei jest de facto własnością państwa chińskiego (Balding, Clarke 2019). Obecnie przedsiębiorstwo zatrudnia blisko 200 tys. pracowników i prowadzi działalność w ponad 170 krajach, a z jego 
usług bezpośrednio lub pośrednio korzystają ponad 3 miliardy ludzi. W 2019 r. przychody Huawei zamknęly się w kwocie 859 mld juanów (123 mld USD), a zysk netto wyniósł 63 mld juanów (9 mld USD) (Huawei Investment \& Holding Co. Ltd. 2019 Annual Report 2020).

Przedsiębiorstwo Samsung zostało założone w 1938 r. w należącym wówczas do Korei Japońskiej mieście Daegu. Choć Samsung jest klasycznym czebolem, to często utożsamia się go z jego najwartościowszą marką - założonym w 1969 r. przedsiębiorstwem technologicznym Samsung Electronics. Ta ostatnia firma, zatrudniająca ponad 300 tys. pracowników, jest największym producentem elektroniki użytkowej na świecie oraz drugim największym przedsiębiorstwem technologicznym pod względem przychodów w 2019 r. (Fortune Global 500 2020), które wyniosły 230 bln wonów (197 mld USD), a zysk netto zamknął się w kwocie 22 bln wonów (18 mld USD) (Samsung Electronics Company Profile, Financials and Metrics 2020).

\section{Metodyka badania}

Głównym celem przeprowadzonego badania było określenie zbudowanego przez dwie wiodące wschodnioazjatyckie marki poziomu lojalności wśród nabywców w Polsce. Po przeanalizowaniu rynku telefonów komórkowych wybrano wiodącego producenta południowokoreańskiego (Samsung) i największego producenta chińskiego (Huawei). Badanie przeprowadzono w marcu 2020 r. na próbie 1200 respondentów metodą CAWI. W skład próby weszło 329 aktualnych użytkowników telefonów Samsung (co stanowi 27\% próby), 604 osoby, które były, ale obecnie nie są użytkownikami telefonów Samsung (50\% respondentów) oraz 267 osób (22\%), które nigdy nie używały telefonów Samsung. W przypadku marki Huawei podobna jest liczba aktualnych użytkowników - 304 osoby (25\% respondentów). Zdecydowanie mniejsza jest liczba osób, które w przeszłości korzystały z telefonów Huawei, ale zdecydowały się na inną markę - 276 respondentów (23\% próby). Największą grupę stanowią osoby, które nigdy nie używały telefonów Huawei. Znalazło się w niej aż 620 osób, co stanowi 52\% próby.

\section{Element behawioralny lojalności wobec marek smartfonów}

Aktualnym użytkownikiem każdej z marek jest co czwarty respondent przeprowadzonego badania. Zdecydowanie większą grupę stanowią byli użytkownicy telefonów Samsung - należy do niej co drugi respondent. Osoby, które kiedykolwiek 
używały telefonów Samsung, stanowią aż 77\% badanej grupy, jednak dwie $\mathrm{z}$ trzech osób nie zakupiły ponownie produktów tej marki. Oznacza to stosunkowo wysoki poziom nielojalności na poziomie behawioralnym.

W przypadku Huawei zdecydowanie mniejsza jest grupa osób, które nie dokonały powtórnego zakupu. Spośród 48\% respondentów, którzy kiedykolwiek byli użytkownikami telefonów Huawei, blisko połowa nie kupiła ponownie smartfonu tej marki. Mimo że nie jest to mała grupa, proporcje te wyglądają lepiej niż w przypadku Samsunga. Bardzo interesujący jest przepływ użytkowników między dwiema analizowanymi markami (Wykresy 1 i 2).

Wykres 1. Lojalność w aspekcie behawioralnym obecnych i byłych użytkowników telefonów Samsung

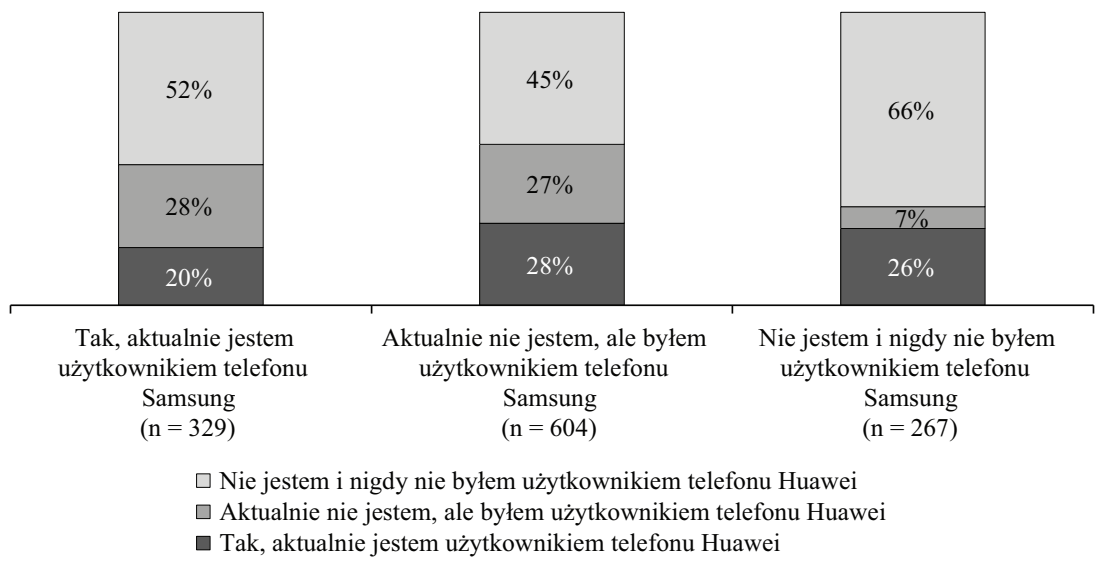

Źródło: opracowanie własne na podstawie wyników badania.

Okazuje się, że 20\% obecnych użytkowników marki Samsung ma równocześnie telefony Huawei, a $28 \%$ zostało przejętych właśnie od Huawei. Ponad połowa używała wcześniej telefonów innych marek. Osoby, które zrezygnowały z Samsunga, często wybierały Huawei $-28 \%$ byłych użytkowników.

Analiza wykazała statystycznie istotne różnice w poziomie lojalności behawioralnej wobec marki Samsung w zależności od płci (test Chi-kwadrat Pearsona, $x^{2}=19,868 ; \mathrm{p}=0,000$ ), wieku (test Chi-kwadrat Pearsona, $x^{2}=56,092$; $\mathrm{p}=0,000$ ), wykształcenia (test Chi-kwadrat Pearsona, $x^{2}=50,261 ; \mathrm{p}=0,000$ ), miejsca zamieszkania (test Chi-kwadrat Pearsona, $x^{2}=47,244 ; \mathrm{p}=0,000$ ) i dochodów (test Chi-kwadrat Pearsona, $x^{2}=123,753 ; \mathrm{p}=0,000$ ).

W zakresie przepływów klientów sytuacja Huawei wygląda korzystniej - aż 56\% obecnych użytkowników tej marki to wcześniejsi posiadacze telefonów Samsunga. Co trzeci były użytkownik telefonu Huawei wybierał później telefony Samsunga, ale aż 59\% wybierało inną markę, mimo wcześniejszych doświadczeń $\mathrm{z}$ telefonami Samsunga. 
Analiza wykazała statystycznie istotne różnice w poziomie lojalności behawioralnej wobec marki Huawei w zależności od wieku (test Chi-kwadrat Pearsona, $x^{2}=67,394 ; \mathrm{p}=0,000$ ), poziomu wykształcenia (test Chi-kwadrat Pearsona, $x^{2}=129,210 ; \mathrm{p}=0,000$ ), miejsca zamieszkania (test Chi-kwadrat Pearsona $\left.x^{2}=40,542 ; \mathrm{p}=0,000\right)$ i dochodu badanych (test Chi-kwadrat Pearsona, $x^{2}=93,617 ; \mathrm{p}=0,000$ ). Test nie wykazał takich różnic $\mathrm{w}$ przypadku płci (test Chi-kwadrat Pearsona, $x^{2}=1,438 ; \mathrm{p}=0,487$ ). Wyniki te potwierdzają wnioski płynące z wcześniejszych badań przeprowadzonych wśród użytkowników smartfonów (Redda, Shezi 2019).

Wykres 2. Lojalność w aspekcie behawioralnym obecnych i byłych użytkowników telefonów Huawei

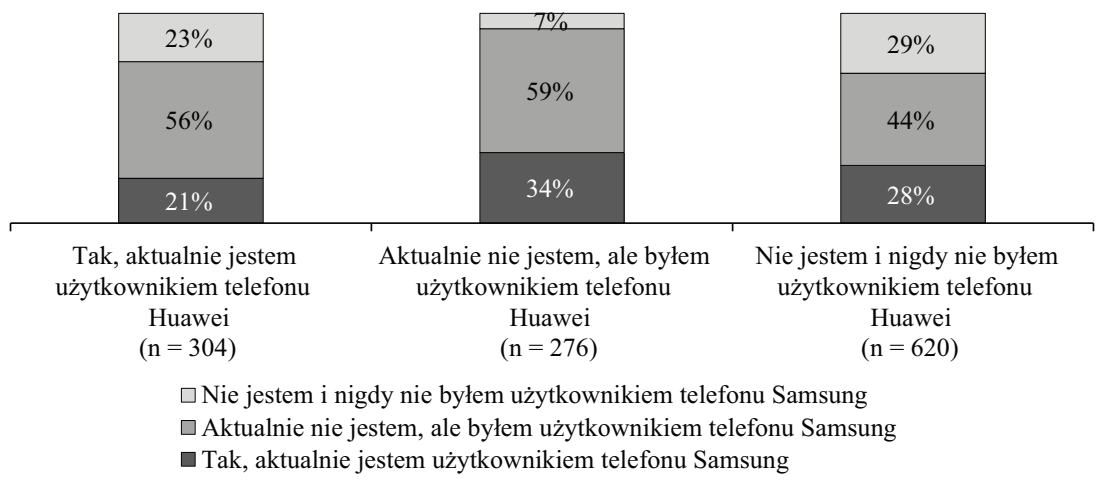

Źródło: opracowanie własne na podstawie wyników badania.

\section{Element emocjonalny w lojalności wobec marek smartfonów}

W celu określenia względnego stosunku nabywców i ich lojalności emocjonalnej wobec badanych marek telefonów respondenci zostali poproszeni o wyrażenie ich postawy w skali od 1 do 10 odnośnie do następujących stwierdzeń: uważam się za lojalnego klienta danej marki; wybratbym dana marke jako pierwsza; jeżeli produkty danej marki bylyby dostępne, nie rozważałbym zakupu innych oraz o zadeklarowanie skłonności do rekomendacji danej marki (także w 10-stopniowej skali).

Wykres 3 prezentuje porównanie poziomu wybranych wskaźników opisujących lojalność całej populacji wobec marek Samsung i Huawei. Produkty Samsunga osiągają lepsze wyniki w przypadku wszystkich wskaźników. Najwyższą wartość w przypadku obu marek osiąga wskaźnik odnoszący się do ich 
rekomendowania - 6,42 dla Samsunga i 5,66 dla Huawei. Należy podkreślić, że użytkownicy telefonów obu marek stanowią około $25 \%$ wszystkich badanych, co może tłumaczyć niezbyt wysoki poziom parametrów.

Wykres 3. Wybrane wskaźniki opisujące lojalność wobec marek Samsung i Huawei, $n=1200$

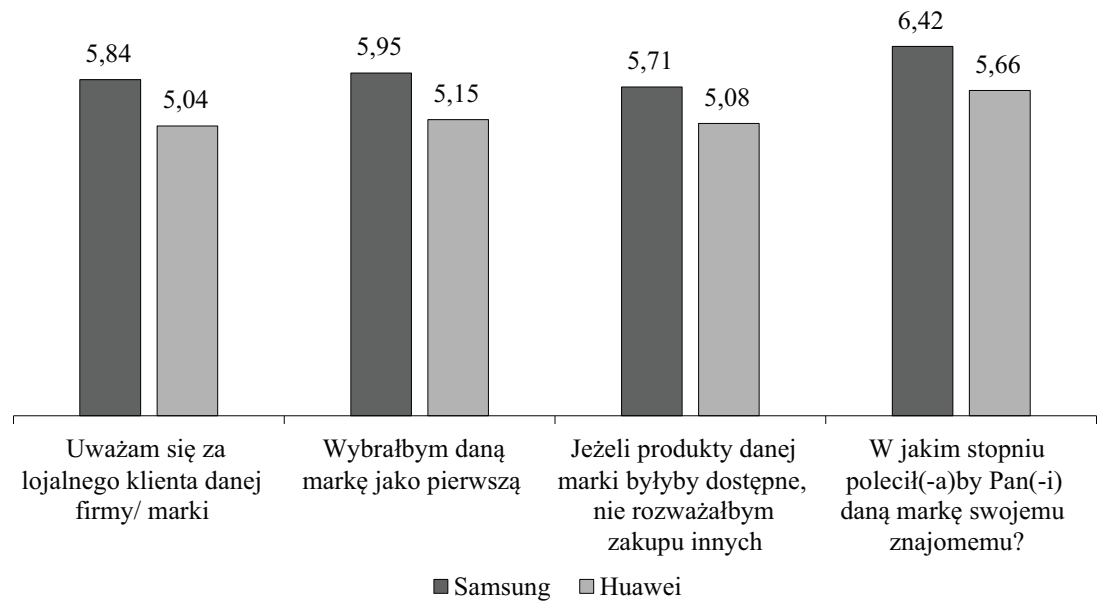

Źródło: opracowanie własne na podstawie wyników badania.

Analiza wariancji wykazała statystycznie istotne różnice w poziomie badanych wskaźników opisujących lojalność wobec Samsunga w zależności od statusu użytkownika (lojalność behawioralną), wykształcenia i dochodu (ANOVA, $\mathrm{p}<0,05 \mathrm{w}$ przypadku wszystkich badanych wskaźników). Z kolei w przypadku miejsca zamieszkania i wieku tej zależności nie ma (ANOVA, $p>0,05$ odnośnie do co najmniej trzech wskaźników).

Wykres 4. Wybrane wskaźniki opisujące lojalność wobec Samsunga według statusu użytkownika

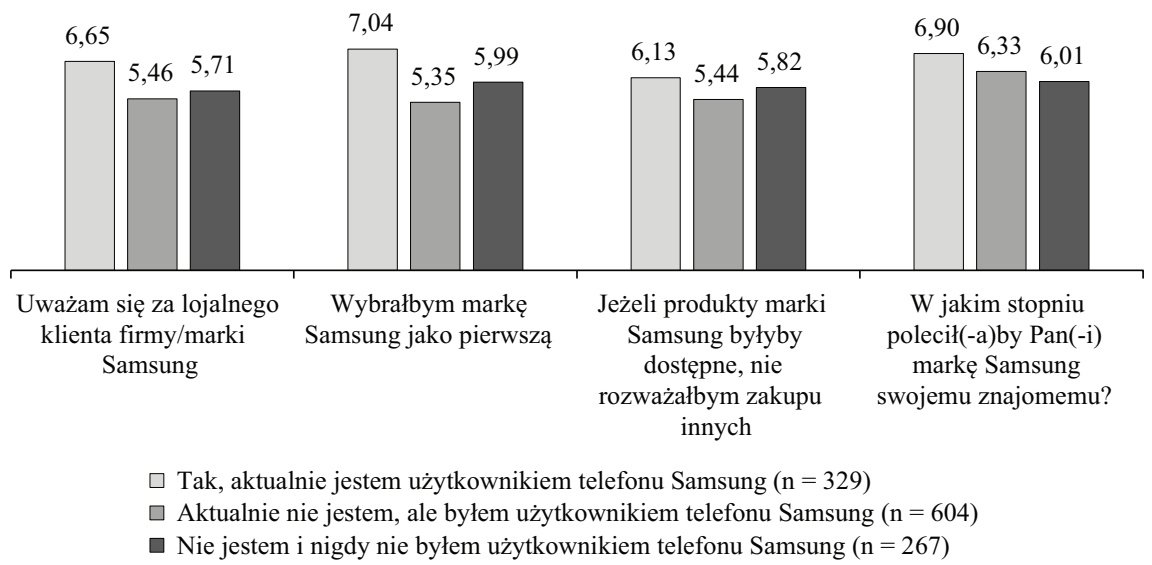

Źródło: opracowanie własne na podstawie wyników badania. 
Wybrane wskaźniki opisujące lojalność osiągają najwyższy poziom - co nie jest zaskakujące - wśród obecnych użytkowników telefonów Samsung. Z kolei najbardziej krytyczni są w tym przypadku byli użytkownicy Samsunga. Co ciekawe, największa różnice zdań wywołało stwierdzenie wybrałbym markę Samsung jako pierwsza (aktualni użytkownicy: 7,04, byli użytkownicy: tylko 5,35). Samsung wypada pozytywnie, jeśli chodzi o skłonność do rekomendacji - parametr ten wśród byłych użytkowników osiąga wyższy poziom niż wśród respondentów, którzy nigdy nie używali telefonów Samsung (odpowiednio 6,33 i 6,01), co jest sytuacją wyjątkową.

Wykres 5. Wybrane wskaźniki opisujące lojalność wobec Samsunga według płci

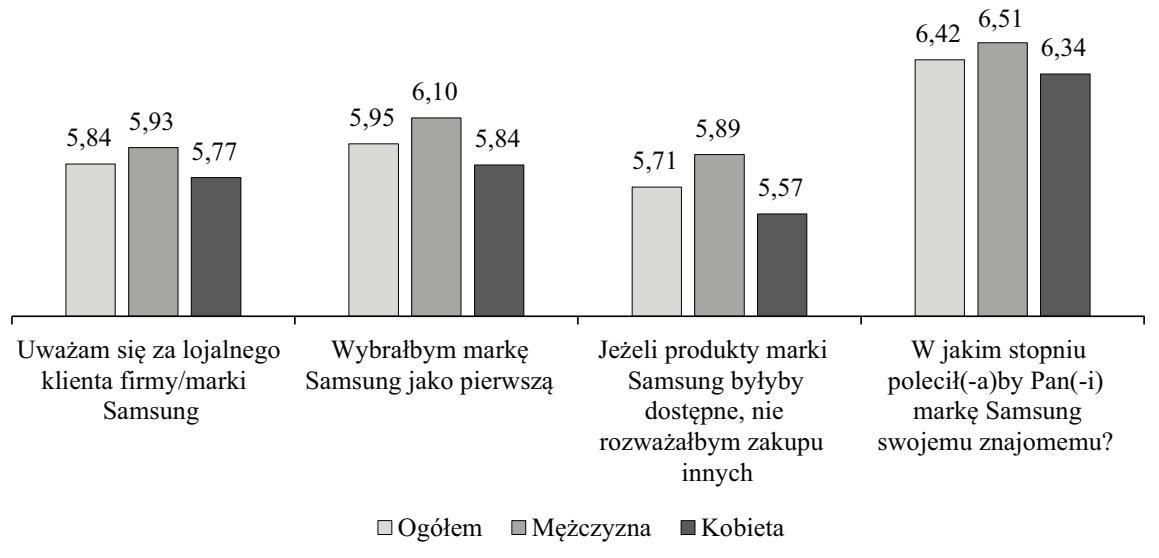

Źródło: opracowanie własne na podstawie wyników badania.

Wyraźnie różne podejście do lojalności wobec marki Samsung mają mężczyźni i kobiety. W przypadku mężczyzn bez wyjątku parametry te osiągają wyższy poziom. Największe różnice wywołuje stwierdzenie jeżeli produkty marki Samsung bytyby dostępne, nie rozważat(-a)bym zakupu innych (mężczyźni: 5,89, kobiety: 5,57 , test t-Studenta, $\mathrm{p}<0,05$ ). Podobne wnioski płyną $\mathrm{z}$ analiz przeprowadzonych wśród użytkowników zarówno Samsunga (Susilowati i Ardhita Putra 2020), jak i innych marek smartfonów (Yeh, Wang, Yieh 2016).

Jeśli chodzi o Huawei, to istotne statystycznie różnice ujawniły się w przypadku statusu użytkownika, wieku, wykształcenia, miejsca zamieszkania, a przede wszystkim dochodu (ANOVA, $p<0,05$ dla wszystkich wskaźników). Różnice dotyczące płci nie są istotne statystycznie (test t-Studenta, $\mathrm{p}>0,05$ dla wszystkich wskaźników).

Podobnie jak w przypadku Samsunga, największą lojalność wobec Huawei deklarują osoby, które obecnie korzystają z telefonów tej marki, co potwierdza wnioski płynące $\mathrm{z}$ opisanych $\mathrm{w}$ literaturze przedmiotu badań empirycznych, zgodnie $\mathrm{z}$ którymi w przypadku użytkowników smartfonów najważniejszym 
czynnikiem kształtującym lojalność jest zadowolenie konsumenta z dotychczasowego użytkowania urządzenia danej marki (Kim i in. 2016; Lin, Huang, Hsu 2015). Wyraźne różnice pojawiają się w przypadku byłych użytkowników - to właśnie byli użytkownicy Samsunga najgorzej ocenili swoją lojalność. Z kolei byli użytkownicy telefonów Huawei wykazują wyższy poziom lojalności niż osoby, które nigdy nie miały do czynienia $\mathrm{z}$ telefonami tej marki.

Wykres 6. Wybrane wskaźniki opisujące lojalność wobec Huawei według statusu użytkownika

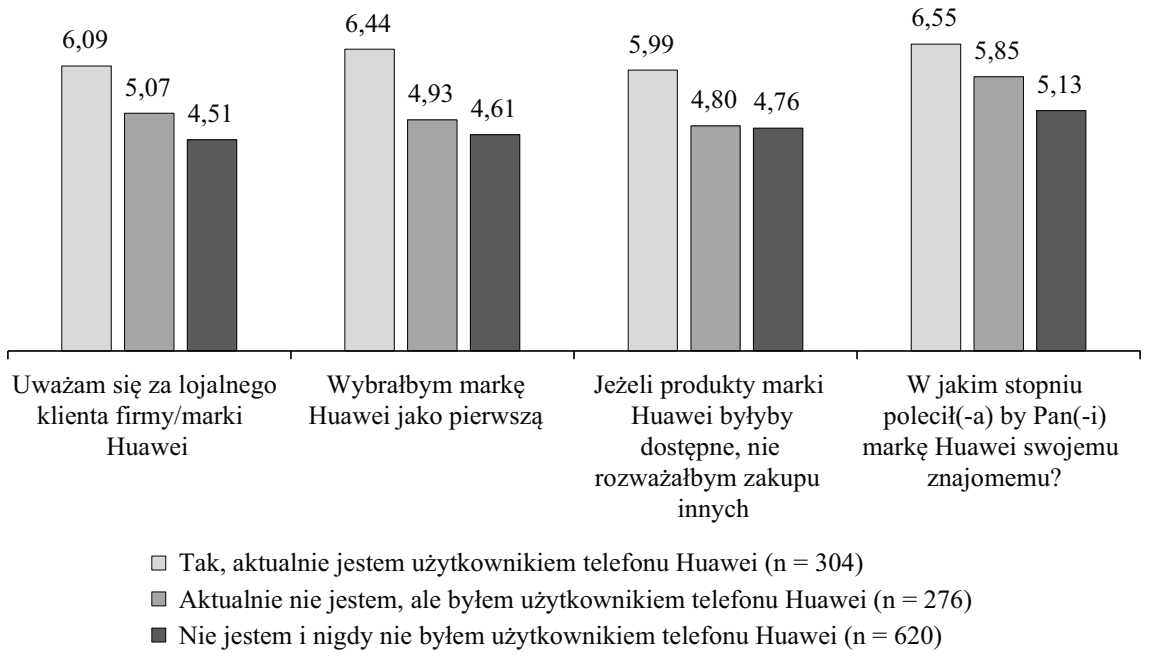

Źródło: opracowanie własne na podstawie wyników badania.

Ciekawa wydaje się analiza parametrów lojalności wobec Huawei w zależności od dochodu (Wykres 7). Jak wcześniej wykazano, różnice te są statystycznie istotne.

Mogłoby się wydawać, że marka, która nie jest zaliczana do grona najbardziej prestiżowych, będzie stosunkowo słabo oceniana przez osoby lepiej zarabiające. Okazuje się jednak, że to osoby z niższymi dochodami zdecydowanie gorzej oceniają poziom swojej lojalności. Przyczyn tego zjawiska należy upatrywać nie w samej marce Huawei, a w sile oddziaływania marek prestiżowych, szczególnie na osoby, dla których marki te nie są dostępne.

Aby określić poziom lojalności, przeanalizowano dodatkowo skłonność do rekomendacji (Net Promoter Score) (Reichheld 2003). Poziom wskaźnika NPS w przypadku Samsunga w odniesieniu do całej badanej populacji wynosi $-30 \%$, a wśród aktualnych użytkowników smartfonów tej marki $-10 \%$. W przypadku Huawei wskaźniki te wynoszą odpowiednio $-52 \%$ oraz $-31 \%$. Wskaźniki te są ujemne w przypadku obu marek, co wskazuje na niski poziom lojalności. 
Wykres 7. Wybrane wskaźniki opisujące lojalność wobec Huawei w zależności od dochodu

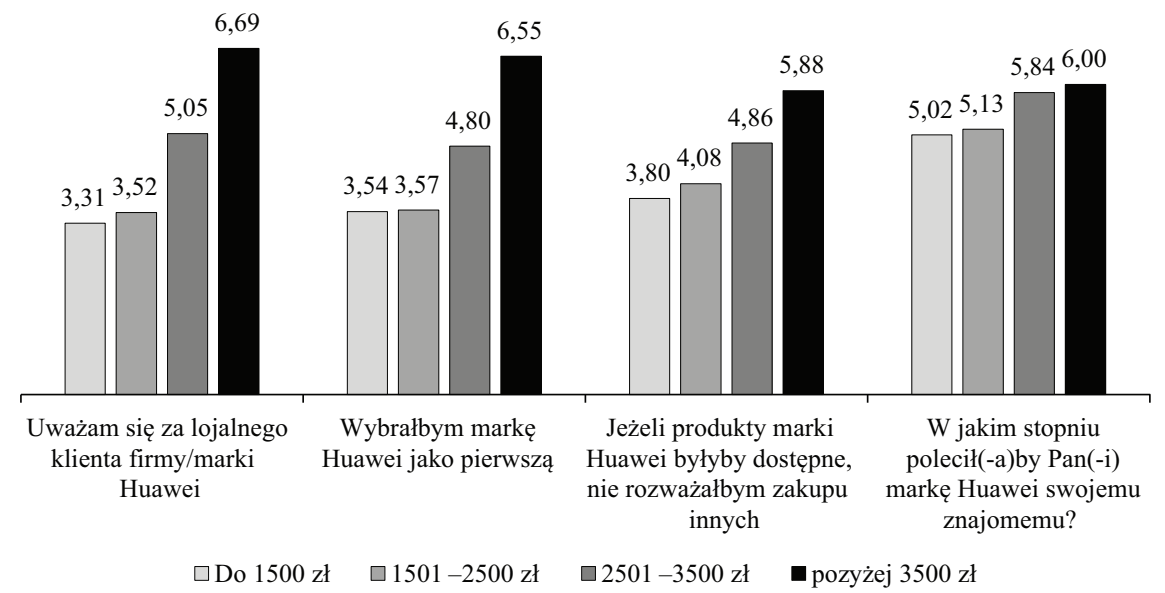

Źródło: opracowanie własne na podstawie wyników badania.

W celu lepszego zobrazowania lojalności emocjonalnej przeanalizowano korelację między parametrami opisującymi lojalność a wybranymi elementami postrzegania marki. Najsilniejsza korelacja w przypadku Samsunga zachodzi między postrzeganiem marki jako niezawodnej a wskaźnikami ogólnej wartości marki. Podobnie sytuacja wygląda w przypadku Huawei (patrz Tabela 3 i 4).

\section{Podsumowanie}

Ocena poziomu lojalności w ujęciu behawioralnym i emocjonalnym nie wykazała istotnych różnic w przypadku obu marek. Aż trzech na czterech respondentów jest lub było użytkownikami Samsunga, ale dwóch z nich nie zakupiło ponownie telefonu tego producenta, wybierając konkurencyjną markę. Jeśli chodzi o Huawei, to co drugi respondent ma doświadczenia związane z marką, przy czym połowa z nich nie dokonała powtórnego zakupu. Wyższy poziom lojalności behawioralnej polskich użytkowników telefonów komórkowych wobec marki Huawei, będący skutkiem korzystniejszego kierunku przepływów użytkowników pomiędzy analizowanymi markami, może wynikać ze wzrastającej świadomości klientów Huawei, strategii cen prestiżowych dla produktów Samsunga oraz rozbieżności między jakością postrzeganą a rzeczywistą jakością tych produktów. Mimo to, jeśli chodzi o lojalność emocjonalną, oceny marki Samsung są istotnie wyższe niż Huawei. Wynika to $\mathrm{z}$ tego, że najwyższe różnice w ocenie występują wśród osób, które nigdy nie były użytkownikami telefonów danej marki, co pokazuje, że Samsung znacznie lepiej buduje wartości symboliczne marki. 
W odniesieniu do kryterium płci warto podkreślić, że mężczyźni wyraźnie wyżej oceniają swoją lojalność wobec Samsunga. Jedną z przyczyn takiego stanu rzeczy może być fakt, że mężczyźni w większym stopniu niż kobiety kojarzą produkty technologiczne z wyznacznikami pozycji społecznej oraz wyróżnikami indywidualizmu. W przypadku Huawei taka zależność nie wystąpiła. Może być to istotna wskazówka dla osób tworzących strategie marketingowe koncernów technologicznych, ukierunkowująca komunikację marketingową przeznaczoną dla mężczyzn na uwypuklanie prestiżu promowanego produktu.

Widać wyraźnie, że bardzo wiele kryteriów segmentacji rynku ma istotny wpływ na różnice w ocenie poziomu lojalności klientów poszczególnych marek. To pokazuje, jak ważne zarówno dla tych marek, jak i innych firm z branży są właściwe stosowanie behawioralnych, demograficznych i geograficznych kryteriów podziału rynku oraz odpowiednia identyfikacja segmentów docelowych.

\section{Bibliografia}

Balding C., Clarke D. (2019), Who owns Huawei? Social Science Research Network, https://papers.ssrn.com/sol3/papers.cfm?abstract_id=3372669 (data dostępu: 21.09.2020).

Baloglu S. (2002), Dimensions of customer loyalty, „Cornell Hotel and Restaurant Administration Quarterly", 6 (February).

Cichosz M. (2003), Lojalność klienta wobec firmy, „Marketing i Rynek”, 8(7).

Cossío-Silva F.J. i in. (2016), Value co-creation and customer loyalty, „Journal of Business Research", 69(5).

Cunningham R.M. (1956), Brand loyalty - what, where, how much?, „Harvard Business Review", 34 (January-February).

Day G.S. (1969), A two-dimensional concept of brand loyalty, „Journal of Advertising Research", 9(3).

Dick A.S., Basu K. (1994), Customer loyalty: Toward an integrated conceptual framework, ,Journal of the Academy of Marketing Science”, 22(2).

Ewing M.T. (2000), Brand and retailer loyalty: Past behavior and future intentions, ,Journal of Product \& Brand Management”, 9(2).

Fortune Global 500 (2020), https://fortune.com/global500/2019/search/?sector=Technology (data dostępu: 22.09.2020).

Givon M. (1984), Variety seeking through brand switching, „Marketing Science”, $3(1)$.

Huawei Investment \& Holding Co. Ltd. 2019 Annual Report (2020), http://www. huawei.com/en/annual-report/2019 (data dostępu: 21.09.2020). 
Iglesias O., Singh J.J., Batista-Foguet J.M. (2011), The role of brand experience and affective commitment in determining brand loyalty, ,Journal of Brand Management", 18(8).

Jacoby J., Kyner D.B. (1973), Brand loyalty vs. repeat purchasing behavior, „Journal of Marketing Research", 10(1).

Jarvis L.P., Mayo E.J. (1986), Winning the market-share game, „Cornell Hotel Restaurant Administration Quarterly", 27 (November).

Jensen J.M., Hansen T. (2006), An empirical examination of brand loyalty, ,Journal of Product and Brand Management", 15(7).

Kabiraj S., Shanmugan J. (2011), Development of a conceptual framework for brand loyalty: A Euro-Mediterranean perspective, „Journal of Brand Management", 18(4-5).

Kahn B., Kalwani D.M. (1986), Measuring variety-seeking and reinforcement behaviors using panel data, „Journal of Marketing Research”, 23(2).

Kim M.K. i in. (2016), Determinants of customer loyalty in the Korean smartphone market: Moderating effects of usage characteristics, „Telematics and Informatics", 33(4).

Knox S., Walker D. (2001), Measuring and managing brand loyalty, „Journal of Strategic Marketing", 9(2).

Lin T.C., Huang S.L. i Hsu C.J. (2015), A dual-factor model of loyalty to IT pro$d u c t$ - The case of smartphones, „International Journal of Information Management", 35(2).

Lotko A. (2018), Pomiar lojalności behawioralnej klientów warsztatów samochodowych, ,The Archives of Automotive Engineering - Archiwum Motoryzacji”, 79(1).

McConnell J.D. (1968), The development of brand loyalty: An experimental stu$d y$, „Journal of Marketing Research”, 5(1).

Michalska-Dudek I. (2013), Pojęcie, rodzaje i motywy lojalności klientów przedsiębiorstw turystycznych, „Prace Naukowe Uniwersytetu Ekonomicznego we Wrocławiu", 304(207).

Mikowska M., Skalna A., Śliwiński K. (2018), Polska jest mobi 2018, http://jestem.mobi/2018/04/raport-polska-jest-mobi-2018-do-pobrania/ (data dostępu: 21.09.2020).

Mittal V., Kamakura W.A. (2001), Satisfaction, repurchase intent, and repurchase behavior: Investigating the moderating effect of customer characteristics, „Journal of Marketing Research”, 38(1).

Ndubisi N.O. (2006), Effect of gender on customer loyalty: A relationship marketing approach, „Marketing Intelligence and Planning”, 24(1).

Number of smartphones sold to end users worldwide (2020), Statista.com, http:// www.statista.com/statistics/263437/global-smartphone-sales-to-end-users-since-2007/ (data dostępu: 21.09.2020). 
Oliver R.L. (1999), Whence consumer loyalty?, „Journal of Marketing”, 63.

Pietrzak J. (2004), Zarzadzanie Procesem Lojalności Konsumenckiej, „Acta Universitatis Lodziensis. Folia Oeconomica", 179.

Punniyamoorthy M., Prasanna Mohan Raj M. (2007), An empirical model for brand loyalty measurement, ,Journal of Targeting, Measurement and Analysis for Marketing", 15(4).

Redda E.H., Shezi N.E. (2019), Antecedents of customer satisfaction and brand loyalty of smartphones among generation Y students, „Polish Journal of Management Studies", 20(2).

Reichheld F.F. (2003), The one number you need to grow, „Harvard Business Review", 81(12).

Şahin A., Zehir C., Kitapçi H. (2011), The effects of brand experiences, trust and satisfaction on building brand loyalty; an empirical research on global brands, „Procedia - Social and Behavioral Sciences”, 24.

Samsung Electronics Company Profile, Financials and Metrics (2020), https:// craft.co/samsung-electronics (data dostępu: 22.09.2020).

Sulikowski P. (2015), Uwarunkowania lojalności, retencji i churnu klientów na przykładzie branży telekomunikacyjnej, „Handel Wewnętrzny”, 3(356).

Susilowati E., Ardhita Putra M.G. (2020), Smartphone Brand Loyalty and Consumer Heterogeneity, „Management: Journal of Sustainable Business and Management Solutions in Emerging Economies", 25(2).

Van Trijp H.C.M., Hoyer W.D., Inman J.J. (1996), Why switch? Product category-level explanations for true variety-seeking behavior, „Journal of Marketing Research", 33(3).

Tucker W.T. (1964), The development of brand loyalty, „Journal of Marketing Research", 1(3).

Worldwide smartphone sales to end users by vendor in 2019 (2020), http://www. gartner.com/en/newsroom/press-releases/2020-03-03-gartner-says-global-smartphone-sales-fell-slightly-in (data dostępu: 21.09.2020).

Xiaomi i Samsung liderami polskiego rynku smartfonów (2020), http://www.wirtualnemedia.pl/artykul/xiaomi-i-samsung-liderami-polskiego-rynku-smartfonow-apple-z-najwiekszymi-wzrostami-xiaomi-smartfony-gdzie-kupic-cena-parametry-opinie (data dostępu: 21.09.2020).

Yeh C.H., Wang Y.S., Yieh K. (2016), Predicting smartphone brand loyalty: Consumer value and consumer-brand identification perspectives, „International Journal of Information Management", 36(3).

Yi Y., Jeon H. (2003), Effects of loyalty programs on value perception, program loyalty, and brand loyalty, ,Journal of the Academy of Marketing Science”, 31(1). 


\section{Streszczenie}

Celem niniejszego artykułu jest ocenienie poziomu lojalności polskich użytkowników smartfonów wobec dwóch marek - Samsunga oraz Huawei. Artykuł zawiera przegląd głównych pojęć i zagadnień związanych z lojalnością nabywców, ze szczególnym uwzględnieniem mocno zarysowanego w literaturze przedmiotu podziału na lojalność behawioralną oraz lojalność emocjonalną. W zależności od powtarzalności zakupów oraz względnego stosunku do marki (lojalności emocjonalnej) wyróżnić można cztery postawy: brak lojalności, lojalność bierną, lojalność ukrytą oraz lojalność prawdziwą.

W artykule przedstawiono najważniejsze dane statystyczne dotyczące rynku smartfonów zarówno w Polsce, jak i na świecie. Aby ocenić lojalność użytkowników smartfonów, porównano dwie marki, Samsung oraz Huawei, które są wiodącymi koncernami technologicznymi i zarazem największymi sprzedawcami telefonów komórkowych na świecie. Zasadniczą część artykułu stanowi analiza wyników badania przeprowadzonego w marcu 2020 r. na próbie 1200 polskich respondentów, z których 329 było użytkownikami smartfonów marki Samsung, a 304 - Huawei. Analizie poddano zarówno lojalność behawioralną, jak i emocjonalną. Zidentyfikowano istotne różnice w ocenie lojalności wobec obu marek wynikające z behawioralnych, demograficznych oraz geograficznych kryteriów segmentacji.

Słowa kluczowe: lojalność, lojalność emocjonalna, lojalność behawioralna, smartfony, telefony komórkowe, Samsung, Huawei, segmentacja

JEL: M20, M31

\section{Summary}

\section{Consumer loyalty to selected smartphone brands}

The purpose of the article is to present the main aspects of brand loyalty among Polish buyers regarding the leading Asian brands of smartphone, Samsung and Huawei. The main definitions of brand loyalty and the theory behind it, especially the distinction between repeat purchasing behavior and brand relative attitude, are discussed. Based on this, it is possible to identify different levels of brand loyalty: no loyalty, latent loyalty, spurious loyalty, and loyalty.

Data concerning the market for smartphones globally and in Poland are presented. The main part of the article, the analysis of brand loyalty, is based on 
empirical research conducted in March 2020 on a sample of 1200 Poles; 329 respondents used Samsung smartphones, and 304 used Huawei. The level of repeat patronage and the relative attitude towards these two brands are measured, and the main differences between the two brands are identified. The main conclusion is that the variations in market segmentation based on demographic, geographic, and behavioral criteria are the main source of these differences.

Keywords: brand loyalty, repeat patronage, repeat purchasing behavior, relative attitude, smartphone, mobile phone, Samsung, Huawei, market segmentation

\section{Załączniki}


Tabela 3. Wskaźniki lojalności i wskaźniki opisujące wizerunek marki Samsung, współczynnik korelacji rang Spearmana (** korelacja istotna na poziomie 0,01 )

\begin{tabular}{|c|c|c|c|c|c|c|c|c|c|c|}
\hline & & 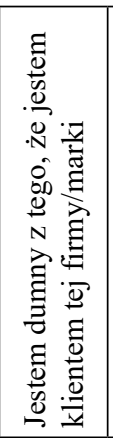 & 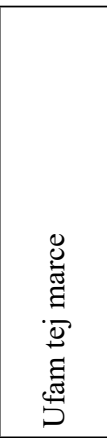 & 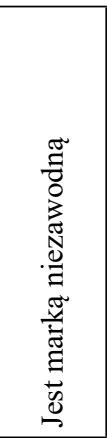 & 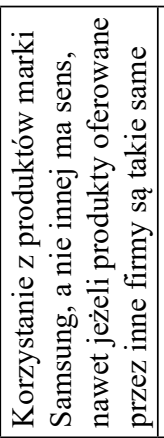 & 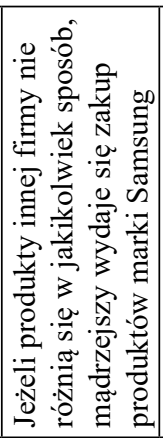 & 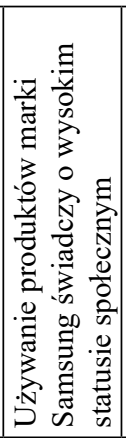 & 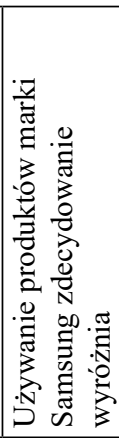 & 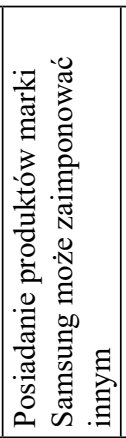 & 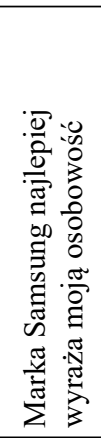 \\
\hline Uważam się za lojalnego klienta firmy/marki Samsung & \multirow{4}{*}{ 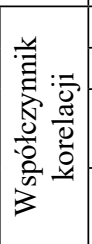 } & $.333 * *$ & $.323 * *$ & $.468 * *$ & $.431 * *$ & $.391 * *$ & $.290 * *$ & $.331 * *$ & $.305^{* *}$ & $.269 * *$ \\
\hline Wybrałbym markę Samsung jako pierwszą & & $.320 * *$ & $.304 * *$ & $.422 * *$ & $.500 * *$ & $.510 * *$ & $.390 * *$ & $.368 * *$ & $.320 * *$ & $.319 * *$ \\
\hline $\begin{array}{l}\text { Jeżeli produkty marki Samsung byłyby dostępne, } \\
\text { nie rozważałbym zakupu innych }\end{array}$ & & $.276^{* *}$ & $.242 * *$ & $.228 * *$ & $.442 * *$ & $.310^{* *}$ & $.203 * *$ & $.282 * *$ & $.249 * *$ & $.292 * *$ \\
\hline $\begin{array}{l}\text { W jakim stopniu polecił(-a)by Pan(-i) } \\
\text { markę Samsung swojemu znajomemu }\end{array}$ & & $.199 * *$ & $.256^{* *}$ & $.213 * *$ & $.539 * *$ & $.183 * *$ & $.138 * *$ & $.107 * *$ & $.116^{* *}$ & $.178 * *$ \\
\hline
\end{tabular}


N Tabela 4. Wskaźniki lojalności oraz wskaźniki opisujące wizerunek marki Huawei, współczynnik korelacji rang Spearmana (** korelacja istotna na poziomie 0,01 )

\begin{tabular}{|c|c|c|c|c|c|c|c|c|c|c|}
\hline & \multirow{3}{*}{ 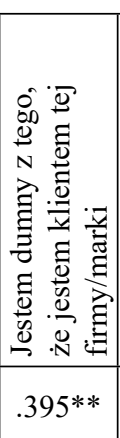 } & \multirow{3}{*}{ 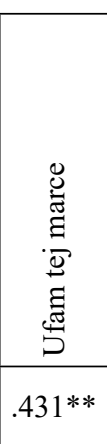 } & \multirow[b]{2}{*}{ 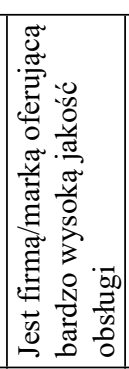 } & & \multirow[b]{2}{*}{ 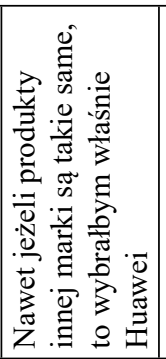 } & \multirow[b]{2}{*}{ 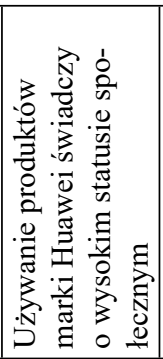 } & \multirow[b]{2}{*}{ 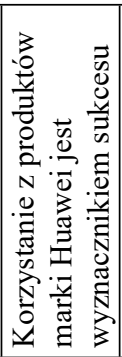 } & \multirow[b]{2}{*}{ 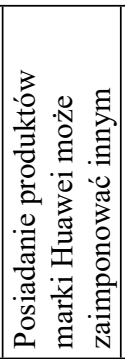 } & \multirow[b]{2}{*}{ 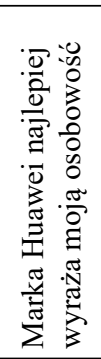 } \\
\hline & & & & & 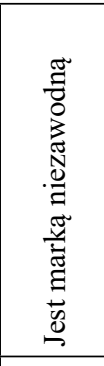 & & & & & \\
\hline $\begin{array}{l}\text { Uważam się za lojalnego klienta firmy/marki } \\
\text { Huawei }\end{array}$ & \multirow{4}{*}{ 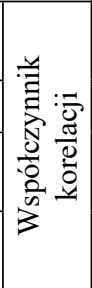 } & & & $.404 * *$ & $.503 * *$ & $.396 * *$ & $.301 * *$ & $.309 * *$ & $.311 * *$ & $.308^{* *}$ \\
\hline Wybrałbym markę Huawei jako pierwszą & & $.385^{* *}$ & $.474 * *$ & $.400 * *$ & $.520 * *$ & $.473 * *$ & $.286^{* *}$ & $.298 * *$ & $.269 * *$ & $.272 * *$ \\
\hline $\begin{array}{l}\text { Jeżeli produkty marki Huawei byłyby dostępne, } \\
\text { nie rozważałbym zakupu innych }\end{array}$ & & $.328^{* *}$ & $.346^{* *}$ & $.240 * *$ & $.311^{* *}$ & $.422 * *$ & $.189 * *$ & $.162 * *$ & $.152 * *$ & $.174 * *$ \\
\hline $\begin{array}{l}\text { W jakim stopniu polecił(-a)by Pan(-i) } \\
\text { markę Huawei swojemu znajomemu? }\end{array}$ & & $.245^{* *}$ & $.337 * *$ & $.210^{* *}$ & $.271 * *$ & $.488^{* *}$ & $.187 * *$ & $.175^{* *}$ & $.131 * *$ & $.150^{* *}$ \\
\hline
\end{tabular}

